Chapter 13

\title{
AGRICULTURAL DEVELOPMENT AND INTERNATIONAL TRADE
}

Kym Anderson and Will Martin

Traditionally societies and their governments have pursued agricultural development to ensure adequate food is available and affordable and incomes of farm households keep pace with those of nonfarm households. Today the farm sector is also expected to care for the natural environment, ensure the food it supplies is safe and nutritious, contribute to energy security, help reduce poverty and greenhouse gas emissions, and provide employment and investment opportunities for women as much as for men. Farm productivity growth can contribute to many of these goals and can be accelerated through more targeted investments in applied agricultural research and in rural infrastructure, education, and health. However, each society does not have to achieve these and their other goals in isolation and indeed will be less able to as climate changes add to the volatility of domestic production. Fortunately, each country's evolving consumption preferences and the wherewithal to satisfy them can be enhanced through trading more openly with other societies. This chapter shows how. It explains the contributions international trade openness can make-and has made-toward achieving these goals. In doing so, the chapter clarifies the role agricultural trade can play, in contrast to trying to remain self-sufficient in food. We draw out the implications for agricultural development prospects in various types of countries as the world economy grows.

Standard economic theory shows that opening to trade will generally raise real national income. The first demonstration of this, by David Ricardo in 1817 , assumes differences in technology between countries and shows that gains from exploiting comparative advantage do not depend on absolute productivity levels but rather on countries' relative productivity in producing different goods. This means that both a poor and a rich country can-at the same time-benefit from being open to trade. The classic example assumes that only labor is used for production and focuses on a poor country that uses more labor to produce each good but still benefits from trade. The poor country can compete despite using more labor hours in producing its export than the rich country because it has a lower wage rate than the rich country. The 
rich country is similarly able to compete in its export commodity, despite having higher wage rates, because it uses labor more efficiently in its export than its import commodity and benefits by being able to import from the poor country.

Although 20th-century trade models accommodate factor endowments as well as productivity differences, they still conclude that both poor and rich countries can gain by trading with each other. A simple indicator of comparative cost advantage in farm products is national agricultural land endowment per worker. Agricultural land per person in the United States in 2005 through 2009 was slightly more than twice the world average, and Brazil's farm land endowment per person was nearly as high. At the other extreme, Japan and Korea had farm land endowments one-tenth of the world average. Little wonder that Brazil and the United States are large agricultural exporters, while Japan and Korea are large agricultural importers. These numbers alone are strongly suggestive of the high costs-to both importers and exporters-that would be associated with trying to be food self-sufficient. Yet some players in developing countries still advocate that policy goal.

The chapter begins by outlining how international trade in farm and other products has contributed to human welfare over the millennia. It then outlines how agricultural production and trade can be expected to change as economies grow. The evolution of agricultural trade patterns has been influenced nontrivially by policy choices of national governments, so they are summarized before turning to the evolution of actual patterns of trade in farm products over the past generation. For a long time agricultural policies had a strong anti-trade bias, but many reforms since the late 1980s have been trade liberalizing. We explain why further trade reform is even more important for developing countries now than in the past, before we conclude by pointing out what more could be done with trade-related policy reforms, together with complementary domestic policies, to further enhance sustainable agricultural development while reducing global income inequality, poverty, food insecurity, and hunger.

\section{The Long History of Agricultural Trade, Briefly}

Long-distance trade has contributed to agricultural development and global economic growth for millennia, but only in recent centuries via intercontinental trade in farmers' outputs. Its predominant contribution in earlier periods was through trade in crop seeds or cuttings, breeding animals, and farm 
production technologies. True, international trade in grain, olives, and wine flourished among Mediterranean countries and their neighbors during the days of the Roman Empire; and silk and spices were exported from China to Eurasia and the Mediterranean for many centuries along the Silk Road (Frankopan 2015). As well, the Hanseatic League facilitated maritime trade farther north into the Baltic states between the 13th and 16th centuries. Then, with Europeans settling in the Americas from the 16th century and opening sea lanes to Asia via South Africa, a few other high-valued unprocessed agricultural products began being transported back to Europe. They included cocoa, coffee, cotton, rubber, spices, sugar, tea, and tobacco. Largescale plantation agriculture developed in Latin America and the Caribbean from the early 1500s, in North America from the early 1600s, and in South and Southeast Asia in the 19th century following European colonization. Once those countries became independent, smallholder agriculture replaced plantations in almost all cases, although there has been a recent resurgence in rubber, oil palm, cassava, and sugarcane plantations in newly opened economies at early stages of demographic and economic transition, such as Cambodia, Lao People's Democratic Republic, and Myanmar (Byerlee 2014).

The complementarity between knowledge of local growing conditions on the one hand and new crops and animals and associated technical know-how on the other (including through the domestic and international transmission of new crop varieties) led to very substantial output growth. That in turn supported population growth. So even though this exchange of farm inputs may not have accelerated GDP per capita or caused commodity prices to equalize across countries prior to 1800 , Jones (2002: chapter 4) argues that it certainly improved agricultural output and national food security in many countries. Perhaps the most notable beneficiary country is China, where four major crops from the Americas (maize, peanuts, sweet potato, and white potato) were being cultivated within a century of Columbus's voyages. Being dryland crops, they did not stress the country's irrigation capability but instead encouraged the conversion of forests to arable land. Jones (2002: 55) notes that this globalizing impact of technical know-how and seed transfer contributed to the world's population increasing about 120 percent between 1500 and 1800, compared with only 18 percent between 1200 and 1500 .

Britain's industrial revolution boosted intercontinental trade in farm products hugely thanks to the steam engine, which lowered the cost of transporting bulky products by rail, river, and sea. That lowering of trade costs encouraged agricultural development in the colonies of European powers 
especially, allowing one or two primary products to dominate the international exports of New World countries in the 19th century (Figure 13.1). Most notable were cotton from the United States and wool from Australia, for Britain's textile industry. But intranational trade in farm products also expanded greatly in all countries where transport infrastructure was developed, especially with railways as in India (Donaldson 2018).

Agricultural growth and trade were further helped by the development of refrigeration from the late 19th century and, in more recent decades, of air freight services that allowed fresh perishable products to be traded over long distances for the first time. That generated gains not only from greater national specialization in production of certain export crops but also through extending the seasonal availability of perishable foods for consumers. In recent decades it has even opened up the possibility for two consuming seasons per year for fresh annual temperate perishables, given the lowered cost of maintaining food safety and quality while transporting food between the Northern and Southern Hemispheres. Since 1800, declining costs of international commerce, and the increasing speed of ocean transport, led to the prices of farm and other products converging across countries, and hence to relative factor prices also converging. O'Rourke and Williamson (2002) as well as Findlay and O'Rourke (2007: 402-405) point to the huge declines in commodity price gaps between Europe and both America and Asia between about 1840 and World War I.

In addition to its contribution to that long-run decline in food (and factor) price gaps across continents, trade between countries has been hugely important in offsetting short-term seasonal shortfalls in food availability (both within and between years). As a consequence, famines are essentially a thing of the past, except where deliberately contrived by a country's leaders for local political purposes (Sen 1981; Ravallion 1987). With lower transport costs and the ever-rising incomes of consumers that raise the demand for variety in all things including foods, coupled with the emergence of modern supermarkets to satisfy those demands, one might expect the range of products available in food markets to have grown exponentially over the past two centuries. That indeed has happened in terms of the number of processed food items available in large affluent cities.

Despite that, just a dozen basic foods account today for 77 percent of the calorie intake and 72 percent of the protein consumed by the world's population, according to FAO Food Balance Sheets. They are three grains (wheat, rice, and maize), four meats (beef, mutton/lamb, pork, and poultry), two edible oils (soybean and palm oil), plus potatoes, milk, and sugar (FAO 2016). 


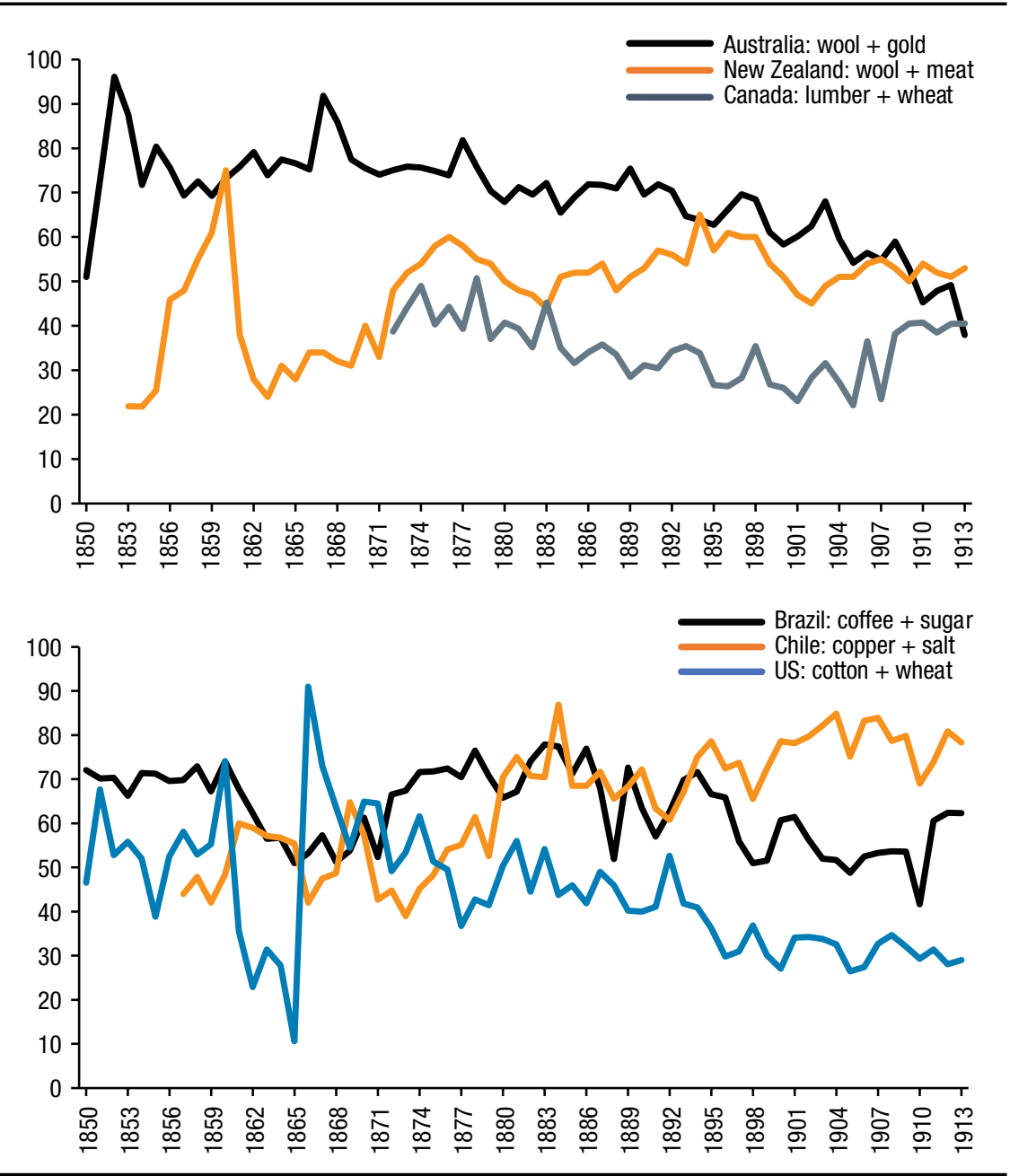

Source: Anderson (2017). Reproduced by permission of the publisher; this figure is not covered by the CC BY 4.0 license.

Those dozen basic farm products could not have become so dominant in the world without international trade in agricultural inputs/technologies or their products, given the small number of regions of the world from which those key species originated. Certainly, fresh fruits and vegetables plus a plethora of processed foods supplement our diets and provide important micronutrients, but a small number of them dominate (bananas, apples, oranges, and other citrus) and have become ubiquitous, thanks to international trade. 


\section{Drivers of Agricultural Production and Trade As Open Economies Grow}

One of the best-known facts about growing economies is that their farm sector's shares of GDP and employment tend to fall. The reasons for those declines in a closed economy are well-known: low and falling income elasticities of demand for food (Engel 1857) plus rapid advances in farm production technologies mean that the domestic prices and quantities of farm relative to nonfarm products fall. It is less obvious that the farm sector of a small open economy-especially one with an abundance of farm land relative to other primary resources, labor, and capital-would have to face relative decline as its economy grows. The fact that it nonetheless almost always does has to do with the rising demand for nontradable goods and especially services as incomes rise. Being nontradable, enough of those products can be produced only by drawing mobile resources from sectors producing tradables. Thus agriculture's shares of national GDP and employment tend to fall with the expansion even of open, land-abundant economies (Anderson and Ponnusamy 2019) at a rate that may also be influenced by relative rates of factor accumulation and differences in sectoral rates of technical change (Martin and Warr 1993).

Agriculture's share of national exports depends on the country's comparative advantage, however, and so need not fall as the world economy expands. Indeed, the tradability of each sector's output increases as trade costs are lowered through investments in transport-related infrastructure. If a country's trade costs fall faster than the rest of the world's, and if its farm products gain more from that development than its nonfarm products, the country may strengthen its agricultural comparative advantage over time. According to the workhorse theory of comparative advantage developed in the 20th century, we should expect agricultural trade to occur between relatively lightly populated economies that are well-endowed with agricultural land and those that are densely populated with little agricultural land per worker. Leamer (1987) develops this model and relates it to paths of economic development. If the stock of natural resources is unchanged, rapid growth by one or more countries relative to others in their availability of produced capital (physical plus human skills and technological knowledge) per unit of available labor time would tend to cause those economies to strengthen their comparative advantage in nonprimary products. By contrast, a discovery of minerals or energy raw materials would strengthen that country's comparative advantage in mining and weaken its comparative advantage in agricultural and other tradable products, ceteris paribus. It would also boost national income and hence the demand for nontradables, which would cause mobile resources to move into 
the production of nontradable goods and services, further reducing farm and industrial production (Corden 1984). Conversely, a depletion or fall in the prices of minerals would strengthen the comparative advantage of agriculture and other sectors producing tradables and weaken the demand for nontradables.

At early stages of economic development, a country with high trade costs typically is agrarian, with most people working on the land and the farm sector producing the majority of GDP when estimated to include home-produced food. If that country has a relatively small stock of agricultural land (and other natural) resources per worker, labor rewards would be low. As trade costs fall or governmental trade restrictions are removed, the country would develop a comparative cost advantage in unskilled labor-intensive, standard-technology manufactures. Then, as the stock of industrial and human capital per worker grows, there would be a gradual move toward exporting manufactures that are relatively intensive in their use of physical capital, skills, and knowledge.

Natural resource-abundant economies, however, may attract migrants from more densely populated countries seeking to become farmers in a frontier region, thereby raising the settler economy's total if not per capita GDP. In such economies the agricultural sector's share of GDP would fall slower than in economies that are growing equally rapidly but are less land-abundant. And if resource-rich economies invest relatively more in capital (including new technologies) specific to primary production rather than to manufacturing, they would not develop a comparative advantage in manufacturing or services until a later stage of development, at which time their exports from those sectors would be relatively capital-intensive. This is all the more likely if new technologies developed for the primary sector become increasingly labor-saving as real wages rise-leading potentially to what are known as factor intensity reversals, whereby a primary industry in a high-wage country can retain competitiveness against a low-wage country by adopting capitalintensive new technologies. And agriculture's share of GDP would decline slower if farm productivity growth outpaced that of other sectors-as it did in high-income countries between 1970 and 2007, according to Herringdorf, Rogerson, and Valentinyi (2013).

Trade patterns are also affected by growth in domestic demands, insofar as preferences are nonhomothetic (Markusen 2013). Food has an income elasticity of demand of less than one, for example. Although this eventually slows the decline in comparative advantage in farm products in resource-poor emerging economies, the rate at which it does is initially slowed by consumers switching from staples to higher-valued foods, including intensively fed 
livestock (Bennett 1941). This theory of sectoral changes and evolving comparative advantages is consistent with global empirical evidence on changes in sectoral shares of GDP, employment, and exports (Anderson and Ponnusamy 2019); and it has been used successfully to explain the 20th-century flying geese pattern of comparative advantage and then disadvantage in unskilled labor-intensive manufactures as some rapidly growing economies expand their endowments of industrial capital per worker relative to the rest of the worldthe classic example being clothing and textiles. The theory has also been used to explain the evolving trade patterns between Asia's resource-poor first- and second-generation industrializing economies and their resource-rich trading partners, and the prolonged importance of agriculture in some New World settler economies such as Australia (Anderson 2017). With the help of newer trade theories, it is also able to explain intra-industry trade and the contribution to productivity growth of opening up (Feenstra 2018).

But trade patterns are also affected by trade-related policy developments. We next summarize a century of such developments before turning to the evolution of actual patterns of trade in farm products.

\section{Policy Developments Affecting Agricultural Trade}

The globalization wave preceding World War I saw substantial liberalization of international trade, including in farm trade (Anderson 2016). Efforts to restore liberal trade following that war centered on international conferences. However, despite rhetoric in support of open markets, those meetings did not lead to renewed trade treaties with binding commitments to openness based on the most-favored-nation (MFN) principle used from 1860 by Britain and France. With no country willing or able to replace Britain as the hegemon, there was trade policy anarchy. When economic recession and low agricultural prices hit in the late 1920s, and the United States introduced the Smoot-Hawley tariff hikes of June 1930, governments elsewhere responded with beggar-thy-neighbor protectionist trade policies that together helped drive the world economy into depression. The volume of world trade shrank by one-quarter between 1929 and 1932, and its value fell by 40 percent. Over the entire interwar period both agricultural and other merchandise trade grew hardly at all. According to Federico (2005: 22-29), world exports of both agricultural and nonagricultural goods declined by 0.8 percent per year between 1925 and 1938, and real prices of farm products in international markets slumped following their highs during World War I. 
The first attempts to reverse the growth in protection were discriminatory, benefiting colonies at the expense of other trading partners. By the end of the 1930 s, protectionism was far more entrenched than in the late 19th century, when only nondiscriminatory tariffs had to be grappled with. Indeed, nontariff trade barriers were so rife as to make tariffs redundant and hence a return to MFN irrelevant unless and until "tariffication" of those barriers occurred. Out of the interwar trade policy experience, Britain and the United States were convinced that liberal world trade required a set of multilaterally agreed rules and binding commitments based on nondiscriminatory principles. After much negotiation, that led to the General Agreement on Tariffs and Trade (GATT). It was signed in 1947 by 23 trading countries-12 high-income and 11 developing - who at the time accounted for nearly two-thirds of the world's international trade (UNCTAD 2018). The GATT provided a forum to negotiate subsequent tariff reductions and changes in rules, plus a mechanism to help settle trade disputes. Eight so-called rounds of negotiations took place in the subsequent 46 years, as a result of which many tariffs on at least manufactured goods were progressively lowered in most high-income countries.

The last of those negotiations, the Uruguay Round (1986-1994), culminated in numerous agreements to further reduce trade barriers over the subsequent decade. One of those agreements involved, for the first time, a serious attempt to liberalize agricultural trade. Another agreement created the World Trade Organization in January 1995 to replace and extend the former GATT Treaty. WTO membership now involves 164 countries/customs territories that account for more than 97 percent of world trade. Global merchandise trade grew faster in the half century following the GATT's formation than in any other half century in history. However, agricultural trade grew less rapidly than trade in other goods, for three reasons. One is the fall in agriculture's share of global GDP (it is now only 3 percent, down from more than 50 percent not much earlier than 1900). A second contributor is the recent fragmentation of industrial production into ever more processes and the associated rapid expansion in the number of links in their global value chains (Baldwin 2016). The latter shows up in the global shares of exports to GDP, which rose during 1995 through 2010 from 66 percent to 105 percent for manufacturing while hardly changing (a rise from 53 percent to 58 percent) for agriculture.

The third key contributor to slow farm trade growth has to do with trade-restricting policies. The lack of strong GATT disciplines on agriculture's trade-related policies allowed two separate developments in farm 
policies between the 1950s and the 1980s: agricultural protection growth in high-income countries, and agricultural export taxation in low-income countries. In both Japan and the European Community in the 1950s, domestic prices exceeded international market prices for grains and livestock products, but by less than 40 percent. By the early 1980s, however, the difference was more than 80 percent for Japan and was around 40 percent for the EC, while still being close to zero for the agricultural-exporting rich countries of Australasia and North America. Nearly all of that assistance to Japanese and European farmers in that period was due to restrictions on imports of farm products. Assistance then rose markedly in the mid-1980s, particularly due to a North Atlantic food export subsidy "war" that was prompted by western Europe seeking to dispose abroad of support-induced output surpluses.

Meanwhile, developing countries had been heavily discriminating against their farmers. A major study of 18 developing countries by Krueger, Schiff, and Valdés (1988) shows that the depression of incentives facing developingcountry farmers from the 1960 s to the mid-1980s had been due partly to various forms of agricultural price and trade policies, including subsidies to food imports as well as taxes on farm exports and partly to developing countries' nonagricultural policies that hurt their farmers indirectly. The two key indirect ones were manufacturing protectionism (which attracts resources from agriculture to the industrial sector) and overvalued exchange rates (which attract resources to sectors producing nontradables, such as services).

A more recent World Bank (Anderson 2009) study covers 45 developing countries but also 13 European transition economies as well as 24 highincome countries. The results reveal that there have been substantial reductions in distortions to agricultural incentives in both high-income and developing countries since the mid-1980s (Figure 13.2). This is also clear from three decades of producer and consumer support estimates of the OECD (2019): the nominal rate of agricultural protection for the 36 OECD member countries (mostly high-income economies) fell from 48 percent in 19861988 to 29 percent in 2000-2002 and 11 percent in 2016-2018, while for 12 (mostly large) emerging economies, the nominal rate of agricultural protection rose on average from 0 percent in 2000-2002 to 5 percent in 20162018. Both these sources also reveal, however, that progress has not been uniform across countries and regions, and that the reform process therefore is far from complete. More specifically, many countries still have a wide dispersion in nominal rates of assistance (NRAs) for different farm industries and in particular have a strong anti-trade bias in the structure of assistance within their agricultural sector. Furthermore, some countries have "overshot" in the 
FIGURE 13.2 Nominal rate of assistance to agriculture in high-income and developing countries, 1955-2014 (\%)

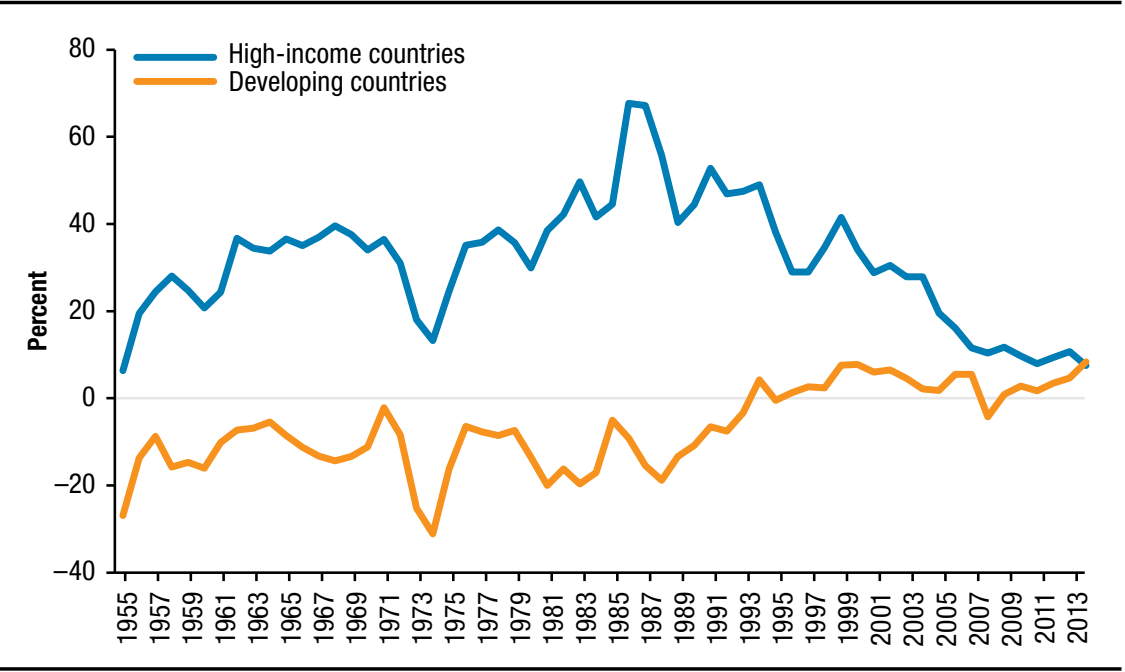

Source: Anderson and Nelgen (2013) to 2011 updated using nominal rates of protection from www.ag-incentives.org (accessed January 2019).

sense that they have moved from having an average relative rate of assistance to farmers (RRA) that was negative to one that is positive, rather than stopping at the welfare-maximizing rate of zero. ${ }^{1}$ Moreover, the variance in rates of assistance across commodities within each country, and in aggregate rates across countries, remains substantial, which indicates that resources within the farm sector of each country and globally are not being put to their best use.

The developing-country average NRA conceals the fact that the exporting and import-competing subsectors of agriculture have very different NRAs. While the average NRA for exporters in developing countries has been negative throughout (but coming back from -50 percent in the 1960s and 1970 s to almost 0 percent in 2000-2010), the NRA for import-competing farmers in developing countries has fluctuated around a trend rate that has risen from 10 percent and 30 percent (and it even reached 40 percent in the years of low international prices in the mid-1980s). This suggests that export-focused farmers in developing countries are still discriminated against in two respects: (1) by the anti-trade structure of assistance within their own agricultural

1 The NRA is the percentage by which gross returns to producers in a sector are raised because of government sectoral or trade policies. RRA is defined as $100^{*}\left[\left(100+\mathrm{NRAag}_{\mathrm{t}}\right) /(100+\right.$ NRAnonag $\left.\left._{t}\right)-1\right]$, where NRAag ${ }_{t}$ and NRAnonag ${ }_{t}$, respectively, are the NRAs for the tradable segments of the agricultural and nonagricultural sectors. 
sectors, and (2) by the protection from imports that remains for farmers in high-income countries. Updated estimates from the agricultural incentives coalition (ag-incentives.org) suggest that by 2014 the NRA for developed and developing countries were essentially the same-a dramatic change from earlier decades (see Figure 13.2).

The improvement in farmers' incentives in developing countries is understated by the above NRA estimates, because those countries have also reduced their assistance to producers of nonagricultural tradable goods, most notably manufactures. The decline in the weighted average NRA for the latter was much greater than the increase in the average NRA for tradable agricultural sectors for the period to the mid-1980s, consistent with the finding of Krueger, Schiff, and Valdés (1988). For the period since the mid-1980s, changes in both sectors' NRAs have contributed to the improvement in farmer incentives. The relative rate of assistance for developing countries as a group went from -46 percent in the second half of the 1970 s to just above 0 percent in the first decade of the current century. This increase (from a coefficient of 0.54 to 1.01 ) is equivalent to an almost doubling in the relative price of farm products, which is a huge change in the fortunes of developing-country farmers in just a generation (Anderson and Nelgen 2013).

The RRA estimates for Asia shed light on something that had perplexed agricultural trade analysts for some time, which is why self-sufficiency in farm products had fallen so little in China and India in recent decades despite their very strong growth in production and exports of manufactures (and of certain tradable services in the case of India): gradual removal of agricultural disincentives encouraged farm output growth even as Asia's industrial competitiveness was strengthening. Within the developing-country group, the spectrum of national RRA estimates remains wide, indicating great scope still for global economic welfare gains from further farm trade liberalization. Such reform not only would raise the mean level of real incomes but also would reduce the variance of international food prices by "thickening" international food markets. According to global economywide modeling results reported in Anderson (2009: chapter 13), liberalization of remaining trade barriers as of 2004 would have raised the share of farm production exported globally from 8 percent to 13 percent. Furthermore, such reform would reduce global income inequality and poverty, according to a follow-up study using numerous global and national economywide models all calibrated to 2004 and incorporating the same World Bank estimates of national price distortions as discussed earlier (Anderson, Cockburn, and Martin 2011). 
The growth in agricultural protection to the mid-1980s added to a downward trend in real international farm product prices following the Korean War in the early 1950s. The developing countries' export taxes, including new ones introduced from around 1960, had a somewhat offsetting effect (Tyers and Anderson 1992). However, with strong global farm productivity growth resulting from agricultural R\&D investments, supply outstripped demand growth and real international food prices trended downward to the mid1980s. Those prices flatlined for the next twenty years, before rising dramatically for a combination of demand, supply, and policy reasons. One of the policy contributors was the emergence of biofuel subsidies and mandates in both the United States and the EU, just at a time when fossil fuel prices were rising for a decade from the early 2000s (Figure 13.3).

Although agricultural trade policies were officially all converted to tariffs following the Uruguay Round, many of the tariff bindings in developing countries are extremely high, allowing considerable flexibility to adjust protection rates below the limits imposed by these commitments. Many policymakers continue to seek to stabilize their domestic prices relative to world market prices by varying the protection or taxation rates applied on agricultural trade in the short run. This insulating behavior may make sense for individual countries, and frequently leads policymakers to think it is the solution to the problems created by commodity price volatility, but such thinking involves a fallacy of composition. This is most easily seen if we consider a case where each country's price is linked to the world price and each country responds in the same way to an increase in world prices. If a tightening of world market conditions raises world prices by $\$ 10$, and all exporters offset this by applying a $\$ 10$ export tax while all importing countries lower their import duties by $\$ 10$ for the same reason, the combined impact is to raise world prices by $\$ 20$ instead of $\$ 10$. Thus domestic prices rise by the same $\$ 10$ they would have risen in the absence of this collectively ineffective intervention (Martin and Anderson 2012; Ivanic and Martin 2014). In this environment only countries that insulate by more than the average can stabilize their prices using this policy (Anderson, Martin, and Ivanic 2017).

Another important form of agricultural trade policy response for staple foods-frequently observed in Africa south of the Sahara-focuses on shocks or perceived shocks to agricultural supply. This often sees export restrictions imposed, or state-traded imports brought in, when domestic output of maize or other key staples are expected to be below normal levels. Such policy responses tend to destabilize both domestic and international markets, and 
FIGURE 13.3 Real international prices of food and fossil fuel (energy), 1960-2016 (2010 = 100 , based on real 2005 US\$)

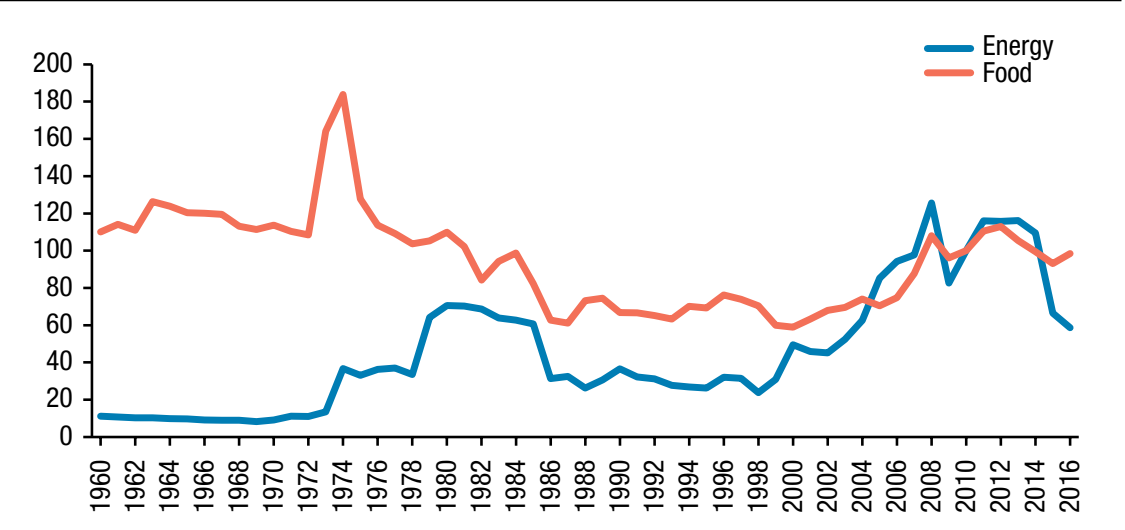

Source: Data from World Bank (2018b).

frequently reduce food security by focusing on the availability of food rather than on the more economically relevant ability of vulnerable groups to access food (Sen 1981).

Recent moves by the United States to a trade policy that seeks liberalization in trading partners by threatening increases in US protection echoes the approaches used for a short time against much smaller Latin American countries in the 1890s (Irwin 2017: chapter 6). Applied to major trading powers such as China, it appears retaliatory responses are bringing serious losses to both parties, including large losses to US agricultural exporters (Robinson and Thierfelder 2019). Hopefully policymakers on both sides will return to reform approaches that generate economic benefits by reducing own-country distortions or agreeing to reciprocal liberalization that generates benefits to both countries.

\section{Agricultural Trade Patterns over the Past Quarter Century}

Much of the discussion of global agricultural trade and associated policies over recent decades has focused on trade between high-income countries and on bulk commodities such as grains, beef, and oilseeds. That discussion does not seem to have caught up with more recent developments that have seen the importance of developing countries grow in world agricultural trade. 
A key driver of the change in farm trade patterns since the early 1990s is the dramatic increase in economic growth rates of developing countries. For the first time since the beginning of the industrial revolution, developing countries have outperformed - by a large margin - the economic growth of the traditionally high-income countries. Between 1950 and 1993, per capita incomes in developing countries consistently fell relative to those in the high-income countries; but between 1993 and 2016 the growth rate of per capita income in developing countries exceeded that of the core high-income countries by an average of 2.5 percentage points per year. As a result, the share of developing countries in world GDP rose from 48 percent in 1993 to 65 percent in 2016. Of course, not all developing countries have grown rapidly since the early 1990s. Figure 13.4 shows that the growth rate of developing-country income in East Asia over this period was astoundingly high, at 6.84 percent per year. It was also relatively high in South Asia, at 4.40 percent per year. The developing countries of Europe and Central Asia and the Middle East and North Africa (MENA) also had growth rates above the high-income country average of 1.43 percent per year. Africa south of the Sahara was equal to the high-income country average, while the growth rate of per capita income in Latin America and the Caribbean was slightly below that average at 1.38 percent per year.

Another key change in the world economy has been a steady decline in the global population growth rate. This decline, from more than 2 percent per year in the mid-1960s, and close to 2 percent per year in 1990, to around 1 percent per year currently and a projected rate of around 0.5 percent per year in 2050, makes growth in per capita incomes relatively more important for food demand in the future than in the past, where global food demand growth was driven primarily by population. These developments have important implications for global food markets and food trade, because of two of the best-known regularities in economics: Engel's Law (Engel 1857; Houthakker 1957) and Bennett's Law (Bennett 1941). The former refers to the fact that the share of food in total spending declines as income rises, while the latter refers to the fact that consumers in middle-income countries transition as their incomes grow from diets dominated by starchy staple foods to diets that include animal products, vegetable oils, and fruits and vegetables. Together these laws mean that income growth in developing countries has a disproportionate impact on global food consumption. Their increase in the demand for animal products is particularly important for total food demand because of the large difference in the cost of producing livestock products relative to plant-based products. 
FIGURE 13.4 Growth rates of per capita income at constant prices, by region, 1993-2016 (\% per year)

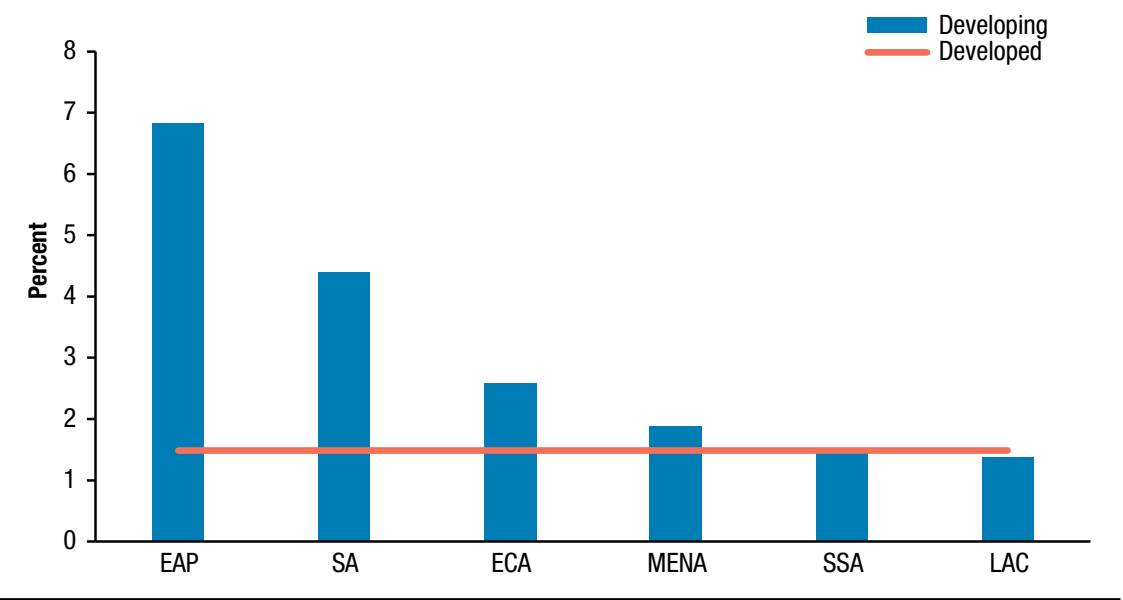

Source: World Bank (2018a), World Development Indicators, accessed April 2020.

Note: EAP = East Asia and Pacific; SA = South Asia; ECA = Central and Eastern Europe and Central Asia; LAC = Latin America and the Caribbean; MENA = Middle East and North Africa; and SSA = Africa south of the Sahara.

Figure 13.5 shows the relationship between income growth and calories consumed (as measured by cereal equivalents) directly by households and the calories required to produce the food bundles demanded at different levels of income. The figure shows how much larger is the energy requirement involved in the production of high-income diets, relative to those consumed by lowincome people. It also shows that the total (direct plus indirect) calorie equivalent consumption increases for much longer as incomes grow than does just the direct consumption of calories. Notice that the growth of food consumption converges on zero as incomes rise in richer countries.

Yet another important development affecting agricultural trade since the early 2000s has been the biofuel policy responses by the United States, the EU, and others to climate change and energy security concerns. The sudden global increase in the demand for maize, oilseeds, and sugar by producers of biofuels in those countries reduced those rich countries' net exports of such farm products and thus raised their prices in international markets. That in turn boosted exports of them from developing countries.

On the supply side of the global food equation, the availability of agricultural land per person has declined over the period since the early 1990s at 
FIGURE 13.5 Direct versus total (direct plus indirect equivalent) calorie consumption, 154 countries, 1992-2009



Source: Fukase and Martin (2016).

Note: $\mathrm{PPP}=$ purchasing power parity; $\mathrm{CE}=$ cereal equivalent; $\mathrm{Kcal}=$ kilocalories; GDP = gross domestic product.

different rates across regions. ${ }^{2}$ Some countries-particularly in Latin America and Africa-have been able to bring new agricultural land into production, while others had little opportunity to do so. Sharp differences between countries in their population growth rates also influence the changes in agricultural land use per person: the declines in land area per person were quite small in Latin America and in East Asian developing countries but more than 15 percent in other regions and more than 30 percent in MENA (Figure 13.6).

Factor endowments are not the only supply-side determinant of farm trade. Agricultural research and development can also impact countries' abilities to export such products. Brazil has emerged as an agricultural export powerhouse in large measure because of rapid farm productivity improvements. The emergence of India as a large exporter of agricultural products, despite a relatively small land endowment per worker, also reflects improved farm

2 “Agricultural land" is defined, as in Fukase and Martin (2016), as arable land plus land in permanent crops and one-third of permanent pasture land. 
FIGURE 13.6 Agricultural land per person, by region, 1992-1997 and 2008-2012 (hectares)

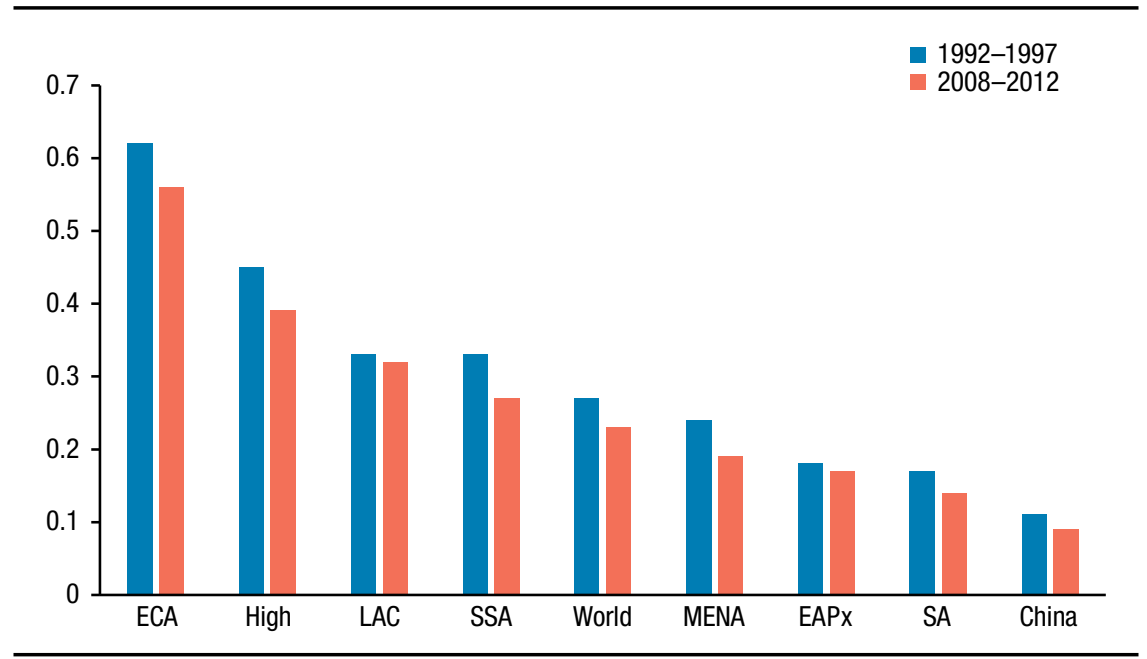

Source: Fukase and Martin (2020).

Note: Regions are based on those used by the World Bank, namely, high = high-income countries; EAPx = East Asia other than China; ECA = Eastern Europe and Central Asia; LAC = Latin America and the Caribbean; MENA = Middle East and North Africa; $S A=$ South Asia; and SSA = Africa south of the Sahara.

productivity. These influences are reflected in the net trade positions of different regions. Figure 13.7 shows a dramatic expansion in the net agricultural exports of Latin America and the Caribbean as well as substantial increases in agricultural imports into China and MENA. Agricultural net exports from developing East Asia other than China also expanded substantially over this period. Net imports of agricultural products into high-income countries (which, as defined by the World Bank, include high-growth economies such as the Republic of Korea) increased from low levels in 1992 to around \$57 billion in 2007, declined as prices in key exporting countries in the group responded to high world prices from 2008 but rose to around $\$ 60$ billion in 2015 and 2016 as lower world prices reduced the incentive to produce.

These influences on agricultural production, consumption, and trade have brought substantial change to the pattern of global farm trade. At the beginning of this growth surge, in 1993, the high-income countries accounted for 56 percent of global agricultural exports and 61 percent of imports. By 2016 there had been an almost complete reversal in terms of importance as both importers and exporters: developing countries contributed 58 percent of those exports and accounted for 60 percent of imports (Table 13.1). That rising importance of developing countries in global farm trade is duplicated with 
FIGURE 13.7 Net exports of agricultural products, by region, 1992-2016 (US\$ billion)

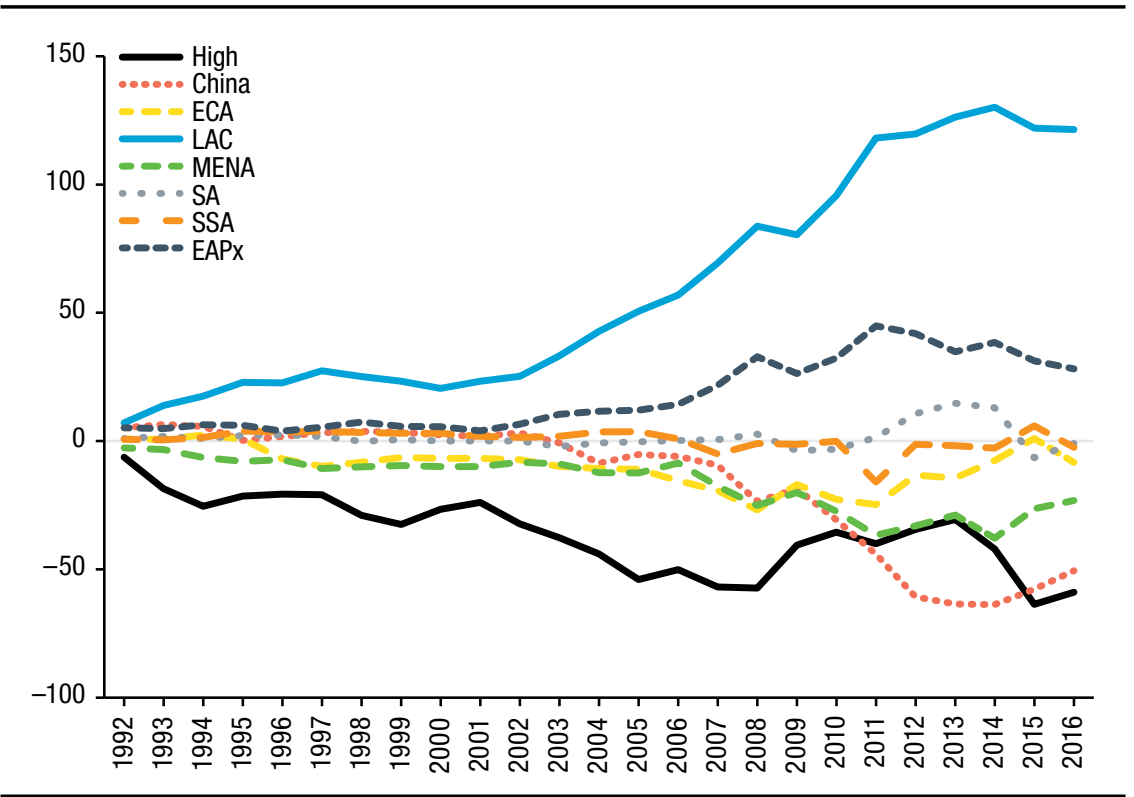

Source: UN COMTRADE data (accessed March 27, 2018, using wits.worldbank.org).

Note: Regions are based on those used by the World Bank, namely, high = high-income countries; EAPx = East Asia other than China; ECA = Europe and Central Asia; LAC = Latin America and the Caribbean; MENA = Middle East and North Africa; $\mathrm{SA}=$ South Asia; and SSA = Africa south of the Sahara.

TABLE 13.1 High-income and developing-country shares of world agricultural trade, 1993 and 2016 (\%)

\begin{tabular}{lccc}
\hline & High-income & Developing & World \\
\hline 1993 & 56 & 44 & 100 \\
Exports & 61 & 39 & 100 \\
Imports & & & \\
& & & \\
2016 & 42 & 58 & 100 \\
Exports & 40 & 60 & 100 \\
Imports &
\end{tabular}

Source: UN COMTRADE data (accessed July 21, 2018, using wits.worldbank.org). Note: Intra-EU trade is excluded from EU and global trade. 
TABLE 13.2 Share of agricultural products in total merchandise exports, major country groups, and world, 1960-2014 (\%)

\begin{tabular}{lcccccc}
\hline Country/country group & $1960 s$ & $1970 s$ & $1980 s$ & $1990 s$ & $2000-2004$ & 2014 \\
\hline Western Europe & 17 & 14 & 13 & 12 & 9 & 11 \\
Japan & 8 & 3 & 2 & 1 & 1 & 1 \\
United States and Canada & 28 & 25 & 20 & 14 & 11 & 13 \\
Australia and New Zealand & 84 & 54 & 45 & 36 & 32 & 25 \\
Subtotal: Above high-income & 22 & 16 & 13 & 12 & 9 & 11 \\
China & 51 & 41 & 20 & 12 & 5 & 3 \\
India & 42 & 36 & 24 & 14 & 8 & 13 \\
All developing countries: & & & & & & \\
Upper-middle-income & - & 41 & 24 & 15 & 10 & 10 \\
Lower-middle-income & - & - & 28 & 18 & 12 & 19 \\
Low-income & 60 & 39 & 29 & 22 & 19 & - \\
World & 27 & 21 & 16 & 12 & 9 & 11 \\
\hline
\end{tabular}

Source: Anderson (2016: Table 4), based on UN COMTRADE data. Reproduced by permission of the publisher; this table is not covered by the CC BY 4.0 license.

Note: $-=$ not available.

their trade in other goods (Baldwin 2016). To get a sense of how their comparative advantages have been changing, it is helpful to calculate two indexes of trade specialization. Over the past half-century, the share of farm products in national exports has been declining for each of the low-, lower-middle-, and upper-middle-income countries, as well as for the high-income group of countries, and so for the world as a whole-until recently when world food prices spiked upward (Table 13.2). A country is defined as having a "revealed" comparative advantage (disadvantage) in agriculture if the share of farm products in its exports exceeds (is less than) that share for the world. For the high-income group, and especially for western Europe, the index of "revealed" comparative advantage in farm products has risen and since the 1990s has averaged close to one. By contrast, that index for upper-middle-income countries has fallen from above two to below one as their manufacturing comparative advantage strengthened; while for low- and lower-middle-income countries, it has hovered around two for the past half century, declining only slightly (Table 13.3).

While imports are not captured in Table 13.3, they are in the index of farm trade specialization reported in Table 13.4, which shows the ratio of exports minus imports to exports plus imports. That index has been slightly negative over the past half-century for high-income countries (above zero for 
TABLE 13.3 Indexes of revealed comparative advantage in agricultural and food products, by region, 1960-2014

\begin{tabular}{lcccccc}
\hline Region & $1960 \mathrm{~s}$ & $1970 \mathrm{~s}$ & $1980 \mathrm{~s}$ & $1990 \mathrm{~s}$ & $\mathbf{2 0 0 0 - 2 0 0 4}$ & $\mathbf{2 0 1 4}$ \\
\hline Western Europe & 0.6 & 0.7 & 0.8 & 1.0 & 1.1 & 1.0 \\
Japan & 0.3 & 0.2 & 0.1 & 0.1 & 0.1 & 0.1 \\
United States and Canada & 1.0 & 1.2 & 1.2 & 1.2 & 1.2 & 1.2 \\
Australia and New Zealand & 3.0 & 2.6 & 2.9 & 3.1 & 3.5 & 2.3 \\
Subtotal: Above high-income & 0.8 & 0.8 & 0.9 & 1.0 & 1.0 & 1.0 \\
China & 2.1 & 2.0 & 1.3 & 1.0 & 0.6 & 0.3 \\
India & 1.6 & 1.8 & 1.7 & 1.6 & 1.4 & 1.2 \\
All developing countries: & & & & & & \\
Upper-middle-income & - & 2.0 & 1.6 & 1.3 & 1.2 & 0.9 \\
Lower-middle-income & - & - & 1.8 & 1.5 & 1.4 & 1.7 \\
Low-income & 2.2 & 1.9 & 1.8 & 1.9 & 2.1 & - \\
World & 1.0 & 1.0 & 1.0 & 1.0 & 1.0 & 1.0 \\
\hline
\end{tabular}

Source: Compiled by Anderson (2016) from UN COMTRADE data. Reproduced by permission of the publisher; this table is not covered by the CC BY 4.0 license.

Note: $-=$ not available. Revealed comparative advantage index is the share of agriculture and food in national exports as a ratio of that sector's share of global exports, hence 1 for the world. 1960s is 1961-1969, except for China which is 1965-1969.

TABLE 13.4 Indexes of trade specialization in agricultural and food products, by region, 1960-2014

\begin{tabular}{lrrrrrr}
\hline Region & $1960 \mathrm{~s}$ & $1970 \mathrm{~s}$ & $1980 \mathrm{~s}$ & $1990 \mathrm{~s}$ & $2000-2004$ & 2014 \\
\hline Western Europe & -0.34 & -0.22 & -0.11 & -0.05 & -0.03 & 0.03 \\
Japan & -0.72 & -0.80 & -0.84 & -0.87 & -0.84 & -0.76 \\
United States and Canada & 0.11 & 0.24 & 0.25 & 0.21 & 0.08 & 0.16 \\
Australia and New Zealand & 0.73 & 0.71 & 0.68 & 0.65 & 0.62 & 0.47 \\
Subtotal: Above high-income & -0.18 & -0.11 & -0.05 & -0.04 & -0.04 & -0.07 \\
China & 0.10 & 0.07 & 0.08 & 0.10 & -0.16 & -0.40 \\
India & -0.12 & 0.15 & 0.18 & 0.29 & 0.10 & 0.33 \\
All developing countries: & & & & & & \\
Upper-middle-income & - & 0.50 & 0.32 & 0.17 & 0.10 & -0.09 \\
Lower-middle-income & - & - & 0.30 & 0.14 & 0.09 & -0.13 \\
Low-income & - & 0.25 & 0.17 & 0.14 & 0.07 & - \\
World & 0.00 & 0.00 & 0.00 & 0.00 & 0.00 & 0.00 \\
\hline
\end{tabular}

Source: Compiled by Anderson (2016) from UN COMTRADE data. Reproduced by permission of the publisher; this table is not covered by the CC BY 4.0 license.

Note: $-=$ not available. Agricultural trade specialization index is net exports as a ratio of the sum of exports and imports of agricultural and food products (so ranging between -1 and +1 , positive for net exporters, and the world index is zero). 1960s is 1961-1969, except for China which is 1965-1969. The final column for China and India refers to 2010-2014; their index values in 2005-2009 were -0.22 and 0.25 , respectively (based on FAOSTAT data). 
Australasia and North America, below zero for western Europe and especially Japan), but it has declined from around 0.5 to -0.1 for middle-income countries and from 0.25 to below 0.1 for low-income countries. These changes in the relative importance and competitiveness of developing countries in world markets for agricultural products has major implications for future policy choices.

\section{Why Further Trade Reform Remains Important for Developing Countries}

Given the major increase in the share of developing countries in global farm trade over the past generation, those countries now have a far greater interest in policies affecting that trade. Both own-country and other-country policies are more important than ever in influencing farm incomes in food-exporting developing countries, in meeting food needs of food-importing countries, and in diversifying the available supply and affordability of safe and nutritious food in all countries (Martin and Laborde 2018). Those policy developments remain important because agricultural trade distortions in both high-income and developing countries still tend to be large, and together they account for two-thirds of the potential gains that could come from global merchandise trade liberalization (Anderson, Martin, and van der Mensbrugghe 2005; Laborde, Martin, and van der Mensbrugghe 2011). It is not just the income gains from further trade reform that matter for welfare in developing countries. Also important are the potential impacts of trade reform on poverty alleviation (since that is the key to solving food insecurity and many of the world's other problems), on malnutrition and hunger, on diet diversity and quality, and on domestic food price volatility.

\section{Poverty Alleviation}

Evidence surveyed by Ravallion (2006) suggests aggregate economic growth differences have been largely responsible for the differences in poverty alleviation across regions. Initiatives that boost economic growth are therefore likely to be helpful in the fight against poverty, and trade liberalization is one such initiative. But cuts to trade barriers also alter relative product prices domestically and in international markets, which in turn affect factor prices. Hence the net effect on poverty depends also on the way those price changes affect poor households' expenditure and their earnings net of remittances. If the consumer and producer price changes (whether due to own-country reforms and/or those of other countries) are pro-poor, then they will tend to reinforce 
any positive growth effects of trade reform on the poor. We know that reforms to the agricultural policies of high-income countries could provide a major source of developing country gains from trade reform. Such reform would boost the demand for unskilled labor and for farm products produced in poor countries. Since two-thirds of the world's poor live in rural areas (Castañeda et al. 2016), and since many poor rural households are net sellers of farm labor and/or food, one would expect such reforms to reduce the number in absolute poverty.

A set of analyses reported in Anderson, Cockburn, and Martin (2011), in which global and national economywide model results are carefully combined with household income and expenditure survey data for nearly a dozen developing countries, tests this hypothesis. It finds strong support for it in most of the country case studies considered. If full global trade reform were to be undertaken, that study concludes that it would reduce the number of people in extreme poverty by at least 26 million, and 87 million would be alleviated from $\$ 2$ per day poverty (Anderson, Cockburn, and Martin 2011; Table 13.4). Bear in mind, too, that those estimates are from comparative static models, and so are underestimates because they do not include the poverty-reducing dynamic effects on economic growth of such reforms.

\section{Malnutrition and Hunger}

Hunger and undernutrition can be eased by trade not only in goods but also in agricultural technologies, in particular newly bred varieties of staple crops. The introduction of high-yielding dwarf wheat and rice varieties during the Green Revolution that began in Asia in the 1960s is a previous case in point, whereby producers and consumers shared the benefits in terms of higher farm profits and lower consumer prices for cereals.

A prospective case in point is the possibility of breeding crop varieties that are not only less costly to grow but are "nutriceuticals" in the sense they contain vitamin and mineral supplements. The most promising is so-called golden rice. Consumers in many poor countries suffer from chronic vitamin A deficiency that can lead to blindness, weakened immune systems, and increased morbidity and mortality for children as well as pregnant and lactating women. Golden rice has been genetically engineered to contain a higher level of beta-carotene in the endosperm of the grain and thereby provide a vitamin A supplement. By being cheaper and/or more nutritionally beneficial, golden rice would improve the health of poor people and thereby also boost their labor productivity. Anderson, Jackson, and Nielsen (2005) estimate that the latter economic benefit from this new biotechnology could be as much as 
ten times greater than just the traditional benefits of lower production costsnot to mention that poor people would live longer and healthier lives.

The benefits of such new biotechnology is being held back in many developing countries where genetically modified organisms (GMOs) have yet to be adopted. This is because the European Union and some other countries will not import from countries whose food may contain GMOs-even though there is no evidence that GM foods are a danger to human health (see, for example, EASAC 2013; UK, House of Commons 2015). The cost of that trade barrier to developing countries has been very considerable both through the loss of export opportunities and the dampening effect on adoption of improved technologies (Anderson 2010; Qaim 2016).

CRISPR approaches to breeding plants and livestock appear to offer additional potential for improving both yields and product quality (Zaidi et al. 2019; Godwin 2019). The fact that these technologies do not require transfers of genes between species and that gene-edited plants and animals are indistinguishable from those bred for the same attributes by conventional techniques may help promote community acceptance. The USDA has announced that it has no plans to regulate plants developed using CRISPR that could have been developed through traditional breeding techniques. However, the European Court of Justice has proposed regulating gene-edited crops under the same strict EU rules as apply to GM foods, and the US Food and Drug Administration has proposed mandatory premarket evaluation of food animals (Van Eenennaam, Wells, and Murray 2019). Clearly, the progress both of gene-editing technologies and of the regulatory responses to them are likely to have important influences on global food production and trade in the coming decades-hopefully with a more positive outcome than the current situation with respect to the regulatory rigidities applying to GMOs.

\section{Dietary Diversity and Quality}

Trade has considerable potential to improve food diversity and quality, particularly in countries that are small and have little agroecological diversity. This advantage of trade is likely to be exploited most by higher-income countries, where people have the spending power to diversify their diets. However, the process of dietary diversification begins at a relatively low level of income as consumers introduce vegetables, fruits, and oils into diets that were formerly focused heavily on basic staples (Bennett 1941). The link between openness to trade and food quality is more controversial. One would expect the higher incomes associated with trade to result in dietary improvements-assuming consumers are knowledgeable about what foods lead to better nutritional 
outcomes. But concerns have been raised about the role of trade, and globalization more generally, in creating nutritional problems, particularly those associated with obesity (for example, Hawkes, Chopra, and Friel 2009).

One strand of this literature (and related media discussion) focuses on Pacific Island countries. Contributions to this literature tend to claim that the precontact diet in these countries was a healthy mix of carbohydrates from root crops with proteins from tropical fish. The experiences of Easter Island and New Zealand (Flannery 1994) raise questions about the sustainability of such diets, particularly as populations grow. Concerns have been raised about the poor health outcomes associated with such imported foods as mutton flaps and turkey tails, and proposed solutions include banning imports of these foods if providing nutrition information is not enough to change diets. However, trade policy is an indirect and inefficient means of improving diets. It frequently leads to domestic firms producing a similar low-quality product and becoming a powerful lobby group against policies that encourage a move away from these products.

Because policymakers have multiple objectives - such as reducing malnutrition from both undernutrition and overconsumption of unhealthy foods, and avoiding hurting the poor-it seems likely that they will need multiple policy instruments to achieve these goals (Martin 2018). Just as in campaigns against smoking, these might include provision of information, attempts to deglamorize these products, excise taxation to discourage consumption, and perhaps "nudges" toward more nutritional foods (Just and Gabrielyan 2016). Whether imports "cause" nutritional problems, policy approaches that focus on trade policy, such as those advocated by Thow et al. (2011), not only stimulate production of undesired goods but also run into problems with WTO rules that distract policymakers away from a focus on nutrition and into unnecessary conflict over trade policy rules and commitments.

\section{Domestic Food Price Volatility}

Trade is often seen as a source of volatility to domestic agricultural markets. The reality is more typically the reverse. If the focus moves from a single, isolated market to one with many supplying and demanding regions linked by low-cost transport, the coefficients of variation of production and prices are likely to come down when trade is opened. Burgess and Donaldson (2010) found that connecting a district in India to the railway network resulted in a very sharp decline-almost the disappearance — of famines in that region. Inter-regional trade in this context was found to be particularly important because, as Donaldson (2018) explains, agricultural output volatility was large 
and internal transport costs extremely high prior to rail connectivity. Thus this work illustrates the positive role of trade in reducing the volatility of food prices and the risk of food insecurity. In his seminal study of the role of trade in famines in British India, Ravallion (1987) concluded that it had a modestly favorable impact on reducing the consumption impact of output shocks, an effect complemented by domestic storage. He found no evidence of "slump famines" in which the income decline associated with harvest failure reduced consumption enough to increase exports.

\section{Trade and Climate Change}

Food consumption by country and region is currently still strongly linked to production. Climate changes that alter the suitability of different regions for production of particular foods are therefore likely to increase the importance of agricultural trade for consumption smoothing (Hertel 2018). Increased output volatility is likely to further increase this importance on an annual basis (Baldos and Hertel 2015). Because the effects of climate change on crop and livestock productivity are expected to be very different across agroecological zones, it is important to assess these impacts at a fine level of detail. An important paper by Costinot, Donaldson, and Smith (2016) develops a new approach for this analysis using data for 1.7 million distinct fields around the world. Their conclusion is that trade would need to play a relatively minor role in adjusting for climate change.

A new paper by Gouel and Laborde (2019) builds on this analysis and raises concerns about key elasticities estimated in the Costinot, Donaldson, and Smith model and its assumed ability of agriculture to draw additional land under cultivation. Building more heavily on the econometric evidence about key parameters, and introducing an opportunity cost for additional land drawn into cultivation, they find that preventing trade adjustments in response to climate change would increase the cost of adjustment by more than 75 percent. That suggests openness to food trade will be far more important in the future, especially if current projections of increased frequency and severity of extreme weather events are vindicated.

\section{What More Could Be Done to Continue the Trade-Related Policy Reform Process?}

Open markets maximize the benefit that international trade can offer to boost global food security and ensure the world's agricultural resources are used sustainably. The decline in costs of trading internationally add to that 
prospect. Also, if global warming and extreme weather events are to become more damaging to food production in some regions, then all the more reason to have openness to international food markets and allow trade to buffer seasonal fluctuations in domestic production. The more countries that do so, the less volatile will be international food prices.

For those countries becoming more food import-dependent as their comparative advantage moves away from agriculture, slowing that process by raising food import barriers worsens rather than improves their national food security and nutrition, since it reduces economic access to food for the vast majority of households. By contrast, public investments to boost farm productivity - while achieving the same end of reducing import dependence-would enhance national economic growth and food security. Improving the efficiency of markets for all key factors of agricultural production (capital, labor, land, and water), and for inputs such as fertilizer and pump power, are additional ways to improve the sustainable use of the world's agricultural resources.

Developing countries still concerned that poor households would be too vulnerable if food markets were unrestricted have another option to consider. They can now invoke generic social safety net measures such as conditional targeted income supplements. Those measures can be made more affordable and more equitable if they are targeted at just the most vulnerable households. This option is far more practical now than just a few years ago, thanks to the information technology revolution that has reduced hugely the cost of administering such handouts, because they can be provided electronically as direct assistance to even remote households so long as they have access to electronic banking.

As for international efforts to reduce food price volatility, the most obvious option is for WTO member countries to agree collectively to desist from altering their food trade restrictions when international food prices spike. That would require binding not only import tariffs but also export taxes at zero or low levels, or reducing the extent of price insulation that contributes so strongly to world price volatility. Now may not seem a propitious time to think about further trade reform, with the US administration apparently thinking that industrial goals can be achieved through tariffs. But the genesis of today's global trading system was the US Reciprocal Trade Agreements Act of 1934, passed shortly after the damage from trade wars set off by the US Smoot-Hawley tariff of 1930 had become clear (Irwin 2008). And the prospects for agricultural trade reform in the industrial countries were surely gloomy when D. Gale Johnson (1973) wrote his seminal World Agriculture in Disarray, highlighting the need for global agricultural trade reform. As the 
costs of those policies became more obvious, and the potential for less costly alternatives more clear, it became possible to reach agreement on large-scale reforms of industrial-country agricultural policies by the end of the Uruguay Round in 1994. A similar challenge lies ahead for WTO members in dealing with the collective action problems remaining in both industrial and developing countries.

Finally, what about the well-being of net sellers of farm products who find it difficult to compete with imported like products? Protecting them from import competition is an extremely inefficient and inequitable way of assisting them. Partly this is because such a policy raises the prices of such products for all households who are net buyers of such goods. It is also inequitable in that it helps such farmers in proportion to their marketed output-and thus helps the biggest/least needy farmers most. Far more efficient would be to reduce any underinvestment in rural infrastructure (to lower transport and communication costs of getting farm products to market) and in agricultural $R \& D$ (to lower farmers' costs of production or raise the quality and thus price of their product). These messages are not new (see, for example, Johnson 1973), but-like the benefits from free trade-they are not intuitively obvious to noneconomists and so need to be repeatedly impressed upon every new generation if good trade-related policies are to prevail.

\section{References}

Anderson, K. 2009. Distortions to Agricultural Incentives: A Global Perspective 1955-2007. New York: Palgrave Macmillan; Washington DC: World Bank.

- 2010. "Economic Impacts of Policies Affecting Biotechnology and Trade." New Biotechnology 27 (5): 558-564.

-2016. Agricultural Trade, Policy Reforms, and Global Food Security. London: Palgrave Macmillan.

- 2017. "Sectoral Trends and Shocks in Australia's Economic Growth." Australian Economic History Review 57 (1): 2-21.

Anderson, K., J. Cockburn, and W. Martin. 2011. "Would Freeing Up World Trade Reduce Poverty and Inequality? The Vexed Role of Agricultural Distortions." The World Economy 34 (4): 487-515.

Anderson, K., L. A. Jackson, and C. P. Nielsen. 2005. "GM Rice Adoption: Implications for Welfare and Poverty Alleviation." Journal of Economic Integration 20 (4): 771-788. 
Anderson, K., W. Martin, and M. Ivanic. 2017. “Food Price Changes, Domestic Price Insulation and Poverty (When All Policy Makers Want to be Above-Average)." In Agriculture and Rural Development in a Transforming World, edited by P. Pingali and G. Feder, 181-192. London: Routledge.

Anderson, K., W. Martin, and D. van der Mensbrugghe. 2005. "Market and Welfare Implications of Doha Reform Scenarios." In Agricultural Trade Reform and the Doha Development Agenda, edited by K. Anderson and W. Martin, 333-399. London: Palgrave Macmillan; Washington DC: World Bank.

Anderson, K., and S. Nelgen. 2013. “Updated National and Global Estimates of Distortions to Agricultural Incentives, 1955 to 2011.” Database uploaded in June at www.worldbank.org/ agdistortions.

Anderson, K., and S. Ponnusamy. 2019. "Structural Transformation to Manufacturing and Services: The Role of Trade." Asian Development Review 36 (2): 32-71.

Baldos, U., and T. W. Hertel. 2015. "The Role of International Trade in Managing Food Security Risks from Climate Change." Food Security 7 (2): 275-290.

Baldwin, R. E. 2016. The Great Convergence: Information Technology and the New Globalization. Cambridge, MA: Harvard University Press.

Bennett, M. 1941. “Wheat in National Diets." Wheat Studies 18 (2): 37-75.

Burgess, R., and D. Donaldson. 2010. "Can Openness Mitigate the Effects of Weather Shocks? Evidence from India's Famine Era.” American Economic Review 100 (2): 449-453.

Byerlee, D. 2014. “The Fall and Rise Again of Plantations in Tropical Asia: History Repeated?” Land 3: 574-597.

Castañeda, A., D. Doan, D. Newhouse, M. C. Nguyen, H. Uematsu, J. P. Azevedo, and World Bank Data for Goals Group. 2016. Who Are the Poor in the Developing World? Policy Research Working Paper 7844, October. Washington, DC: World Bank.

Corden, W. M. 1984. “Booming Sector and Dutch Disease Economics: Survey and Consolidation.” Oxford Economic Papers 36 (3): 359-380.

Costinot, A., D. Donaldson, and C. Smith. 2016. "Evolving Comparative Advantage and the Impact of Climate Change in Agricultural Markets: Evidence from 1.7 Million Fields around the World." Journal of Political Economy 124 (1): 205-248.

Donaldson, D. 2018. "Railroads of the Raj: Estimating the Impact of Transportation Infrastructure." American Economic Review 108 (4-5): 899-924.

EASAC (European Academies Science Advisory Council). 2013. Planting the Future: Opportunities and Challenges for Using Crop Genetic Improvement Technologies for Sustainable Agriculture. EASAC Policy Report 21. Halle, Germany: EASAC Secretariat, June. 
Engel, E. 1857. “Die Productions und Consumtionsverhältnisse des Königreichs Sachsen.”

Zeitschrift des Statistischen Bureaus des Königlich Sächsischen Ministerium des Inneren 8-9: $28-29$.

FAO (Food and Agriculture Organization of the United Nations). 2016. Food Balance Sheets. Accessed April 4, 2016. http://faostat.fao.org/site/368/default.aspx\#ancor.

Federico. G. 2005. Feeding the World: An Economic History of Agriculture, 1800-2000. Princeton, NJ: Princeton University Press.

Feenstra, R. C. 2018. "Alternative Sources of Gains from International Trade: Variety, Creative Destruction, and Markups." Journal of Economic Perspectives 32 (2): 25-46.

Findlay, R., and K. H. O'Rourke. 2007. Power and Plenty: Trade, War and the World Economy in the Second Millennium. Princeton, NJ: Princeton University Press.

Flannery, T. 1994. The Future Eaters. New York: Grove Press.

Frankopan, P. 2015. The Silk Roads: A New History of the World. London: Bloomsbury.

Fukase, E., and W. Martin. 2016. "Who Will Feed China in the 21st Century? Income Growth and Food Demand and Supply in China." Journal of Agricultural Economics 67 (1): 3-23.

_. 2020. "Economic Growth, Convergence, and World Food Demand and Supply." World Development 132 (August): 1-12.

Godwin, I. D. 2019. Good Enough to Eat? Next Generation GM Crops. London: Royal Society of Chemistry.

Gouel, C., and D. Laborde. 2019. “The Crucial Role of International Trade in Adaptation to Climate Change.” Mimeo. IFPRI, updated August 2019 version of NBER Working Paper 25221, November 2018.

Hawkes, C., M. Chopra, and S. Friel. 2009. “Globalization, Trade, and the Nutrition Transition.” In Globalization and Health: Pathways, Evidence and Policy, edited by R. Labonte, T. Schrecker, C. Packer, and V. Runnels, 235-262. New York: Routledge.

Herrendorf, B., R. Rogerson, and A. Valentinyi. 2013. "Two Perspectives on Preferences and Structural Transformation." American Economic Review 103 (7): 2752-2789.

Hertel, T. 2018. "Climate Change, Agricultural Trade and Global Food Security." Background paper for The State of Agricultural Commodity Markets 2018. Rome: FAO.

Houthakker, H. 1957. “An International Comparison of Household Expenditure Patterns, Commemorating the Centenary of Engel's Law.” Econometrica 25 (4): 532-551.

Irwin, D. 2008. Trade Liberalization: Cordell Hull and the Case for Optimism. New York: Council of Foreign Relations.

-2017. Clashing over Commerce. Chicago: University of Chicago Press. 
Ivanic, M., and W. Martin. 2014. "Implications of Domestic Price Insulation for Global Food Price Behavior." Journal of International Money and Finance 42: 272-288.

Johnson, D. G. 1973. World Agriculture in Disarray. Revised edition. London: Macmillan, 1991.

Jones, E. 2002. The Record of Global Economic Development. Cheltenham, UK: Edward Elgar.

Just, D., and G. Gabrielyan. 2016. "Food and Consumer Behavior: Why the Details Matter." Agricultural Economics 47 (S1): 73-83.

Krueger, A. O., M. Schiff, and A. Valdés. 1988. "Agricultural Incentives in Developing Countries: Measuring the Effect of Sectoral and Economy-Wide Policies." World Bank Economic Review $2(3): 255-272$.

Laborde, D., W. Martin, and D. van der Mensbrugghe. 2011. "Potential Real Income Effects of Doha Reforms." In Unfinished Business? The WTO's Doha Agenda, edited by W. Martin and A. Mattoo, 255-275. London: Centre for Economic Policy Research; Washington DC: World Bank.

Leamer, E. E. 1987. "Paths of Development in the Three-Factor, n-Good General Equilibrium Model." Journal of Political Economy 95 (5): 961-999.

Markusen, J. R. 2013. “Putting Per-Capita Income Back into Trade Theory.” Journal of International Economics 90 (2): 255-265.

Martin, W. 2018. "Food Trade Policy and the Dietary Transition." OCP Policy Center, Policy Brief PB-18/07. www.policycenter.ma/publications/food-trade-policy-and-dietary-transition.

Martin, W., and K. Anderson. 2012. "Export Restrictions and Price Insulation During Commodity Price Booms." American Journal of Agricultural Economics 94 (2): 422-427.

Martin, W., and D. Laborde. 2018. "The Free Flow of Goods and Food Security and Nutrition.” In Global Food Policy Report, 20-29. Washington DC: International Food Policy Research Institute.

Martin, W., and P. G. Warr. 1993. “Explaining Agriculture’s Relative Decline: A Supply Side Analysis for Indonesia." World Bank Economic Review 7 (3): 381-401.

OECD (Organisation for Economic Co-operation and Development). 2019. Producer and Consumer Support Estimates database. Accessed August 31, 2019. www.oecd.org.

O’Rourke, K. H., and J. G. Williamson. 2002. “When Did Globalisation Begin?” European Review of Economic History 6 (1): 23-50.

Qaim, M. 2016. Genetically Modified Crops and Agricultural Development. London: Palgrave Macmillan.

Ravallion, M. 1987. Markets and Famines. London: Oxford University Press.

_. 2006. "Looking beyond Averages in the Trade and Policy Debate." World Development 34 (8): 1374-1392. 
Robinson, S., and K. Thierfelder. 2019. “Who's Winning the US-China Trade War? It's Not the United States or China." Peterson Institute for International Economics, Washington DC. Sen, A. 1981. Poverty and Famines. London: Oxford University Press.

Thow, A., P. Heywood, J. Schultz, C. Quested, S. Jan, and S. Colagiuri. 2011. "Trade and the Nutrition Transition: Strengthening Policy for Health in the Pacific." Ecology of Food and Nutrition 50 (1): 18-42.

Tyers, R., and K. Anderson. 1992. Disarray in World Food Markets: A Quantitative Assessment. New York: Cambridge University Press.

UK, House of Commons. 2015. Advanced Genetic Techniques for Crop Improvement: Regulation, Risk and Precaution. Fifth Report of Session 2014-15, Science and Technology Committee, House of Commons, Parliament, London.

UN (United Nations). 2018. COMTRADE database. Accessed March 27, 2018. wits.worldbank .org.

UNCTAD (United Nations Conference on Trade and Development). 2018. UNCTADSTAT data on Merchandise Trade. Accessed April 5, 2018. http://unctadstat.unctad.org/wds/ TableViewer/tableView.aspx?ReportId=10.1.

Van Eenennaam, A., K. Wells, and J. Murray. 2019. "Proposed U.S. Regulation of Gene-Edited Food Animals Is Not Fit for Purpose." Science of Food 3: 3.

World Bank. 2018a. World Development Indicators database. Accessed January 17, 2018. http:// wdi.org.

_.2018b. Pink Sheets database. Accessed February 27, 2018. www.worldbank.org/en/ research/commodity-markets.

Zaidi, S., H. Vanderschuren, M. Qaim, M. Mahfouz, A. Kohli, S. Mansoor, and M. Tester. 2019. "New Plant Breeding Technologies for Food Security." Science 363 (6434): 1390-1391. 